\title{
An interaction map for HTLV-1 Tax and PDZ-containing proteins
}

\author{
Karim Blibek $^{1 *}$, Xavier Rambout ${ }^{1}$, Jérôme Beaufays ${ }^{2}$, Laurence Lins ${ }^{2}$, Franck Dequiedt ${ }^{1}$, Jean-Claude Twizere \\ From 16th International Conference on Human Retroviruses: HTLV and Related Viruses \\ Montreal, Canada. 26-30 June 2013
}

Human T-cell leukemia virus type 1 (HTLV-1) retrovirus encodes for the Tax protein, which has a transforming capacity in vitro. Tax contains at its $\mathrm{C}$-terminus a binding motif for PDZ domain-containing proteins (PSD95DLG1-ZO1). It has been shown that the C-terminal motif of Tax is involved in Tax oncogenic capacity. Ten different PDZ domain-containing proteins have been reported to interact with Tax, but the specificity of Taxhuman PDZome interactions has not been investigated. The objective of this study is to obtain a comprehensive interactome map for Tax and the human PDZome and to determine a global role of Tax-PDZ interactions in HTLV-1 biology. By using different protein-protein interaction methods we have generated a Tax/human PDZome interaction map. We then performed a clustering analysis to define biological functions associated with Tax/PDZ interactions. PDZ Proteins involved in cell shape, cytoskeleton organization and membrane polarization and traffic were overrepresented, and suggest that Tax/PDZ interactions may be involved in Tax-mediated stimulation of $\mathrm{T}$ cell activation pathways.

\section{Authors' details}

${ }^{1}$ National Fund for Scientific Research, Interdisciplinary Cluster for Applied Genoproteomics (GIGA), University of Liège, Liège, Belgium. ${ }^{2}$ National Fund for Scientific Research, Gembloux Agro-Bio Tech, Center of Numerical

Molecular Biophysics, University of Liège, Gembloux, Belgium.

Published: 7 January 2014

doi:10.1186/1742-4690-11-S1-P101

Cite this article as: Blibek et al:: An interaction map for HTLV-1 Tax and PDZ-containing proteins. Retrovirology 2014 11(Suppl 1):P101.
National Fund for Scientific Research, Interdisciplinary Cluster for Applied Genoproteomics (GIGA), University of Liège, Liège, Belgium

Full list of author information is available at the end of the article
Submit your next manuscript to BioMed Central and take full advantage of:

- Convenient online submission

- Thorough peer review

- No space constraints or color figure charges

- Immediate publication on acceptance

- Inclusion in PubMed, CAS, Scopus and Google Scholar

- Research which is freely available for redistribution
() Biomed Central
C Biomed Central

(C) 2014 Blibek et al; licensee BioMed Central Ltd. This is an Open Access article distributed under the terms of the Creative Commons Attribution License (http://creativecommons.org/licenses/by/2.0), which permits unrestricted use, distribution, and reproduction in any medium, provided the original work is properly cited. The Creative Commons Public Domain Dedication waiver (http:// creativecommons.org/publicdomain/zero/1.0/) applies to the data made available in this article, unless otherwise stated. 